\title{
Bentuk Dan Jaringan Patron-Klien Politik Uang Pada Pemilu Legislatif Tahun 2019 Di Kabupaten Tasikmalaya
}

\author{
Perhat Alfaz ${ }^{1}$ Suswanta $^{2}$ \\ ${ }^{1,2}$ Program Studi Ilmu Pemerintahan, Universitas Muhammadiyah Yogyakarta. Indonesia. \\ ${ }^{1}$ Korespondensi Penulis Perhat.alfaz.2014@fisipol.umy.ac.id
}

\begin{abstract}
Abstrak: Politik uang dalam perhelatan pemilu legislatif tahun 2019 di Kabupaten Tasikmalaya adalah keniscayaan yang sulit dihindarkan. Jauh sebelum pemilu berlangsung, Bawaslu merilis Indeks Kerawanan Pemilu (IKP) 2019 sebagai upaya preventif terjadinya pelanggaran dalam pemilu. Berdasarkan hasil IKP 2019 Kabupaten Tasikmalaya memiliki tingkat kerawanan tinggi menempati urutan pertama dalam subdimensi kampanye dengan skor 77,08, dimana politik uang termasuk bagian di dalamnya. Pasca pemilu berlangsung, laporan pelanggaran banyak diterima Bawasalu, lima diantaranya menyangkut pelanggaran politik uang dan hanya ada satu kasus yang terbukti memenuhi syarat formil dan materil sehingga bisa sampai pada putusan pengadilan. Maksud dari penelitian ini mencoba untuk mengungkap bagaimana bentuk dan jaringan patron-klien politik uang yang terjadi pada pemilu legislatif tahun 2019 di Kabupaten Tasikmalaya. Penelitian ini menggunakan metode deskriptif kualitatif, dengan teknik pengumpulan data dengan wawancara, dokumentasi dan studi literatur. Hasil penilitian mengungkapkan bahwasannya praktik politik uang dalam pemilu legislatif tahun 2019 di Kabupaten Tasikmalaya banyak terjadi, hanya saja ada yang dilaporkan secara resmi ke Bawaslu dan ada yang dibiarkan begitu saja tidak dilaporkan. Ada enam jenis politik uang yang ditemukan, diantaranya: Vote buying, Individual gifts, Vote Tradding, Club goods, Services and activities dan Pork Barrel Project. Dari keenam jenis politik uang tersebut, kasus yang paling dominan ditemukan adalah vote buying sebanyak lima laporan yang resmi diterima Bawaslu, dengan pola penyebaran praktiknya melibatkan tim sukses yang didominasi oleh jaringan keluarga dan jaringan sosial. Strategi politik uang juga berpengaruh signifikan terhadap meningkatnya partisipasi pemilih di Kabupaten Tasikmalaya. pada pemilu 2014 partisipasi pemilih di Kabupaten Tasikmalaya mencapai angka 65 persen dan terjadi kenaikan partisipasi pemilih pada pemilu serentak tahun 2019 menjadi 71 persen.
\end{abstract}

Kata kunci: Politik Uang, Pemilu, Patron-Klien

\begin{abstract}
Money politics in the 2019 legislative elections in Tasikmalaya Regency is a necessity that is difficult to avoid. Long before the election took place, Bawaslu released the 2019 Election Vulnerability Index (IKP) as an effort to prevent violations in the election. Based on the results of the 2019 IKP, Tasikmalaya Regency has a high level of vulnerability and ranks first in the campaign sub-dimension with a score of 77.08, where money politics is part of it. After the election took place, Bawasalu received many reports of violations, five of which involved money politics violations and there was only one case that was proven to meet the formal and material requirements so that it could arrive at a court decision. The purpose of this study is to try to reveal how the form and network of patron-client money politics occurred in the 2019 legislative elections in Tasikmalaya Regency. This study uses a qualitative descriptive method, with data collection techniques with interviews, documentation and literature study. The results of the study revealed that the practice of money politics in the 2019 legislative elections in Tasikmalaya Regency occurred a lot, it's just that some were officially reported to Bawaslu and some were left unreported. There were six types of money politics found, including: Vote buying, Individual gifts, Vote Trading, Club goods, Services and activities and Pork Barrel Project. Of the six types of money politics, the most dominant cases found were vote buying as many as five reports officially received by Bawaslu, with the pattern of spreading the practice involving a success team dominated by family networks and social networks. Money politics strategy also has a significant effect on increasing voter participation in Tasikmalaya Regency. In the 2014 election, voter participation in Tasikmalaya Regency reached 65 percent and there was an increase in voter participation in the 2019 simultaneous elections to 71 percent.
\end{abstract}

Keywords: Money Politics, Election, Patron-Client

Article History:

Received : 2021-07-01

Revised : 2021-08-14

Accepted : 2021-08-26

PENDAHULUAN

Pada milu legislatif tahun 2019 tingkat kerawanan pemilu yang tinggi hampir tersebar di seluruh daerah di Indonesia, termasuk di Kabupaten Tasikmalaya Provinsi Jawa Barat, tingkat 
kerawanan berdasarkan dimensi penyelenggara pemilu yang bebas dan adil skornya 61,84 dan subdimensi kampanye memperoleh skor 77,08 yang berati Kabupaten Tasikmalaya dalam status kerawanan tinggi dan menempati urutan pertama di Provinsi Jawa Barat. Maka politik uang yang termasuk dalam bagian variabel subdimensi kampanye jelas akan mengancam pemilu serentak 2019 di Kabupaten Tasikamalaya sehingga perlu diperhatikan lebih lanjut dan dilakukan upaya pencegahan untuk meminimalisir potensi kerawanannya.

Tabel 1. Subdimensi Kampanye Kabupaten/Kota di Jawa Barat dengan Kerawanan Tinggi:

\begin{tabular}{clc}
\hline Peringkat & \multicolumn{1}{c}{ Kabupaten/Kota } & Skor \\
\hline 1 & Kabupaten Tasikmalaya & 77.08 \\
\hline 2 & Kabupaten Bogor & 68.75 \\
\hline & Sumber: Data IKP 2019 Bawaslu
\end{tabular}

Berkaca pada penyelenggaraan pemilihan umum (pemilu) dan pemilihan kepala daerah (pilkada) beberapa waktu sebelumnya, di Kabupaten Tasikmalaya potensi pelanggarannya cukup besar dan politik uang menjadi salah satu pelanggaran yang paling berpotensi akan terjadi. Benar saja, pasca berlangsungnya pemungutan suara, Bawaslu Kabupaten Tasikmalaya menerima beberapa laporan dugaan kasus praktik politik uang. Ada 13 laporan yang ditangani oleh Sentra Penegakan Hukum Terpadu (Gakumdu). Kasus yang ditangani terjadi hampir diseluruh dapil yang ada di Kabupaten Tasikmalaya dengan terlapor salah satu calon anggota legislatif untuk Kabupaten, Provinsi dan Pusat. Dalam keterangan lain, di Kabupaten Tasikmalaya hampir di semua kecamatan terdapat dugaan politk uang yang dilakuakan oleh tim sukses dari Partai Gerinda yang memiliki hubungan dengan salah satu pengusaha di Tasikmalaya dengan membagi-bagikan uang hingga jumlahnya mencapai sebesar 30 miliar melalui jaringan tim suksesnya untuk memenangkan kandidat secara paketan, mulai dari capres, caleg DPR RI, caleg DPRD Provinsi dan caleg DPRD Kabupaten.

Faktanya dari banyak dugaan pelanggaran pemilu kategori politik uang, hanya ada 5 laporan yang diterima oleh Bawaslu dan itupun hanya ada satu kasus yang bisa ditangani sampai dikeluarkannya putusan pengadilan dikarenakan adanya bukti yang kuat serta memenuhi unsur formil dan materil sedangkan yang lainya dihentikan karena tidak memenuhi syarat. Pada pemilu yang telah berlangsung, menetapkan caleg terpilih atas nama Agung Nugraha Putra nomor urut 3 dari Partai Gerindra daerah pemilihan 7 Kabupaten Tasikmalaya di diskualifikasi dan mendapat hukuman pidana penjara selama 5 bulan dan denda sejumlah 5 juta rupiah karena terbukti membagi-bagikan uang sebesar 1,2 juta melaui jaringan tim sukes yang masih berada dalam ikatan keluarga atas nama Iding Suryadi. Sedangkan Iding Suryadi sendiri hanya dikenakan hukuman wajib lapor selama 3 bulan dan dendan uang sebesar 3 juta rupiah (Putusan Nomor 170/Pid.Sus/2019/PN Tasikmalaya).

Politik uang merupakan perkara yang tidak bisa ditolerir apapun alasannya, karena politik uang akan mengacaukan jalannya demokrasi yang dicita-citakan. Namun aturan yang berlaku saat ini mengenai politik uang dan sanksi hukuman bagi pelakunya dirasa masih belum memiliki efek jera, karena setiap perheletan pesta demokrasi politik uang semakin massif terjadi, itu menandakan masih adanya kelemahan dan celah hukum pada peraturan tersebut. Kasus politik uang yang terjadi di Kabupaten Tasikmalaya dalam pemilu serentak tahun 2019 dapat di tinjau dari sudut pandang jaringan patron-klien yang merupakan hubungan timbal balik pertukaran keuntungan demi memperoleh dukungan politik (Aspinall \& Sukmajati, Patronase dan Klientelisme dalam Politik Elektoral di Indonesia, 2015). Lebih lanjut (Hanif, 2009) menerangkan jaringan patron-klien merupakan sebuah hubungan yang ditandai oleh pemberian sumberdaya ekonomi dan politik dari patron dalam hal ini caleg yang memiliki kekuasaan personal dan adanya pamrih loyalitas dan dukungan politik dalam hal ini klien. 
Jaringan patron-klien tersebut kemudian bekerja satu sama lain dengan praktik politik uang menjadi aktivitas didalamnya demi mendulang suara untuk pemenangan caleg dan keuntungan ekonomi serta kekuasaan menjadi imbalan yang diperoleh klien. Maka dari itu penelitian ini mencoba untuk menganalisis masalah tentang bagaimana bentuk praktik politik uang bekerja yang melibatkan adanya jaringan ptaron-klien dalam pemilu serentak tahun 2019 di Kabupaten Tasikamalaya dan hanya berfokus pada kontestasi pemilihan calon anggota legislatif terutama di dapil 7 yang meliputi Kecamatan Sodong Hilir, Taraju, Puspahiang, Salawu dan Bojong Gambir. Dipiihnya dapil 7 dikarenakan melihat kondisinya secara umum persaingan antar caleg di dapil 7 sangat kompetitif, tokoh-tokoh partai dan caleg petahana banyak berasal dari dapil ini mereka memiliki pengaruh besar, baik di lingkungan partainya sendiri maupun di lingkungan daerah pemilihannya sehingga menjadikan dapil 7 daerah yang paling rawan terjadinya politik uang di Kabupaten Tasikmalaya, terbukti dengan banyaknya laporan politik uang berasal dari dapil ini, hingga akhirnya ada satu laporan di Bawaslu yang sampai pada putusan pengadilan.

\section{METODE PENELITIAN}

Metode yang digunakan dalam penelitian ini adalah deskriptif kualitatif atas dasar pertimbangan pada faktor-faktor yang berkaitan dengan topik penelitian, informasi yang diperlukan, persepsi tentang realitas dan ketersediaan bahan. Penelitian ini menggunkan pendekatan kualitatif bertujuan untuk memahi fenomena sosial yang mendalam dan tersembunyi di bawah permukaan diantara peneliti dan fenomena yang sendang diteliti. Sehinga harapannya dapat mengungkap dan membuka fakta yang sebenarnya terjadi diantara hubungan patron-klien caleg dan aktor lainnya yang terlibat dalam pemilu serentak tahun 2019 di Kabupaten Tasikmalaya. Maka untuk mengetahui dan memahami model praktik politik uang tersebut, sumber yang didapatkan berasal dari berbagai data yang berupa tulisan maupun katakata atau dokumen yang berasal dari sumber yang diteliti dan kebenarannya dapat dipecaya.

\section{HASIL DAN PEMBAHASAN Bentuk-Bentuk Politik Uang}

Sistem pemilu porposional terbuka yang sudah di lakukan semenjak pemilu tahun 2009 menjadi salah satu faktor yang berpengaruh besar bagi perilaku caleg untuk melakukan strategi politik uang. Dalam sistem proporsional terbuka, setiap caleg mau tidak mau dipaksa harus bertarung dengan sesama caleg dalam satu partainya. Akibat dari persaingan internal partai ini lah, setiap caleg dituntut untuk membangun jaringannya sendiri yang melampaui struktur partai. Dalam penelitiannya, Muhtadi (2018) memaparkan bahwa pada pemilu 2014 tingkat kompetisi internal seluruh partai politik sangat tinggi, selisih kemenanganya berkisar antara $1,40 \%$ dan $2,48 \%$. Sedangkan rata-rata margin kemenangan diantara caleg yang lolos dan yang tidak lolos hanya $1,65 \%$. Jadi bagi setiap caleg hanya membutuhkan selisih $1,65 \%$ untuk bisa mendapatkan kursi menjadi anggota dewan. Hal itu masih berdampak kuat pada pemilu legislatif tahun 2019 khususnya di lokasi penelitian yang penulis lakukan. Masih banyak caleg meyakini bahwa dengan strategi politik uang akan menambah suara yang akan mereka dapatkan. Maka dari itu banyak caleg berharap meraih kemenangan dengan strategi politik uang. Belum lagi sistem pemilu proposional terbuka kali ini dilakukan secara serentak dengan pemilihan Presiden dan Wakil Presiden, hal ini berdampak terhadap beberapa tim sukses caleg bekerja lebih keras secara tandem dengan tim sukses capres dan cawapres, karena ada tambahan sumber pemasukan uang yang lebih banyak, sehingga jika diantara mereka melakukan politik uang, akan menjadi politik uang paketan untuk memenangkan caleg beserta capres-cawapresnya.

Praktik politik uang di Kabupaten Tasikmalaya masih diyakini oleh para caleg sebagai salah satu strategi jitu untuk meraup suara yang tinggi dan melibatkan semua elemen mulai 
dari caleg itu sendiri, konstituen serta penyelenggara pemilu ikut andil dalam pratik politik uang. Keterlibatan para caleg dan kontituen dalam praktik politik uang diperparah dengan keterlibatan penyelenggara pemilu yang seharusnya bersikap independen. Nihilnya praktik politik uang yang terjadi di pemilu legislatif tahun 2019 di Kabupaten Tasikmalaya tidak semuanya dilaporkan kepada Bawaslu, beberapa faktor diantaranya adalah karena minimnya pengertahuan masyarakat akan politik uang itu sendiri, misalnya mana yang termasuk politik uang dan mana yang tidak, salah satunya ajakan memilih caleg dengan imbalan uang mereka anggap bukan praktik politik uang. Lainnya masyarakat merasa ketakutan apabila harus melaporkan praktik politik uang kehidupan mereka akan terancam dan dikucilkan dilingkungan tempat tinggalnya. Adapun yang mengetahui praktik politik uang tersebut tapi tidak melaporkannya karena paham kurangnya bukti ataupun tidak memenuhi syarat.

\section{Pembelian Suara (Vote Buying)}

Vote buying pada pemilu legislatif tahun 2019 di Kabupaten Tasikmalaya merupakan strategi yang banyak dilakukan caleg untuk memenangkan suara dalam pemilu, karena jika hanya mengandalkan strategi persnonalistik saja tidak akan cukup, harus ditunjang dengan bersamaan dengan strategi materialistik. Dalam praktiknya transaksi yang dilakukan antara caleg baik secara langsung oleh caleg itu sendiri maupun melalui perantara tim sukses dan broker kepada pemilik hak suara akan di bagikan secara bertahap yaitu pada saat masa kampanye, masa tenang atau beberapa hari sebelum hari pemungutan suara, targetnya adalah pemilih yang sudah menjadi basis pendukungnya. Bahkan bisa dibagikan secara acak kepada siapa saja pada saat waktu hari pemungutan suara tiba bebera jam sebelum pemilih pergi ke TPS (tempat pemungutan Suara), ini lah yang di sebut dengan istilah "serangan fajar" atau sekarang muncul lagi istilah baru "serangan dhuha" karena waktu praktiknya saat waktu dhuha.

Vote buying terbagi menjadi dua bentuk, yaitu dalam bentuk uang dan barang, berikut uraiannya:

\section{Uang}

Dalam pemilu legislatif tahun 2019 di Kabupaten Tasikmalaya praktik politik uang dengan transaksi menggunakan uang itu sendiri sebagai alat pertukaran suara antara caleg dan pemilih merupakan paling banyak barang bukti laporannya. Uang adalah salah satu modal utama yang harus dimiliki oleh para caleg untuk berkompetisi meraup suara sebanyak-banyaknya. Alihalih uang yang harusnya digunakan untuk biaya operasional pencalonan malah di gunakan untuk menyuap pemilih agar memperoleh suara yang tinggi.

Demi perolehan suara yang tinggi, para caleg rela berkorban untuk melakukan apa saja, termasuk mengeluarkan uang yang banyak untuk membeli suara pemilih. Berdasarkan laporan pelanggaran politik uang yang diterima Bawaslu, vote buying yang dilaporkan semuanya dalam bentuk uang. sedangkan nominal uang yang di bagikan bervariatif, paling kecil nomilnalnya mulai dari 20 ribu hingga paling tinggi 250 ribu. Dari keseluruhan temuan politik uang yang dilaporkan kepada Bawaslu hanya ada satu terlapor atas nama Agung Nugraha Caleg DPRD Kabupaten Tasikmalaya dari partai Gerindra dapil 7 yang kasusnya ditindak lanjuti sampai ke pengadilan. Sedangkan kasus yang lainnya tidak bisa ditindak lanjuti ke tahap selanjutnya karena tidak memenuhi syarat.

\section{Barang}

Dalam pemilu serentak 2019 di Kabupaten Tasikmalaya bukan hanya uang yang menjadi alat transaksi pertukaran suara akan tetapi berupa barang pun marak ditemukan sebagai alternatif transaksi pengganti uang anatara caleg dan pemilih. Bagi para caleg barang diayakini sebagai alat tukar yang paling aman dan tidak beresiko besar, sehingga mereka tidak akan dituduh telah melakukan praktik politik uang dan terhindar dari pelanggaran pemilu. Modus 
pemberian barang kepada pemilih dari caleg banyak sekali motifnya, salah satunya bagi-bagi sembako dengan dalih sebagai bentuk sedekah biasa, padahal ada motif supaya dapat imbalan ingin dipilih. Hal itu berjalan efektif untuk menghindari dari jeratan aturan yang berlaku. Pada dasarnya baik caleg maupun pemilih menganggap melakukan pemberian barang atau menerima barang merupakan suatu hal yang wajar, akibat anggapan yang keliru diantara kedua aktor itulah politik uang menjadi bertambah subur di pemilu.

Maraknya politik uang dalam bentuk barang dianggap tidak kalah lebih efektif dibandingkan dengan pemberian uang, kebanyakan masyarakat mengaku menerima kedua bentuk materi tersebut. Untuk barang yang dibagikan sendiri tidak terlalu bermacam-macam, kebanyakan yang dibagikan kain sarung untuk laki-laki dan kerudung atau mukena untuk perempuan. Alasanya jelas kenapa yang dibagikan adalah atribut keagaaman atau perlengkapan ibadah karena supaya terkesan lebih religius, sebab di Kabupaten Tasikmalaya sendiri mayoritas masyarakatnya pemuluk agama islam, hampir disetiap desa ada pondok pesantren, hal itulah yang menjadikan Tasikmalaya dijuluki "Kota Santri." Walaupun begitu tidak ada jaminan masyarakatnya bebas dari politik uang, perilaku politiknya dalam politik elektoral masyarakat Kabupaten Tasikmalaya masih banyak yang ikut terlibat politik uang, tentunya itu tidak sesuai dengan nilai-nilai ajaran islam yang menjujung nilai kebaikan dan mengharamkan suap-menyuap, maka tidak menjamin lingkungan yang religius dapat terhindar dari praktik politik uang.

\section{Pemberian-Pemberian Pribadi (Individual Gifts)}

Individual gifts dalam setiap pelaksanaan pemilu pasti terjadi, hanya saja untuk membedakan antara pemberian barang-barang pribadi dengan pembelian suara sangat sulit untuk dibedakan. Individual gifts biasannya hanya dijadikan strategi pendukung untuk melengkapi upaya pembelian suara yang lebih sistematis, jadi sifatnya bukan yang utama. Para caleg yang melakukan praktik ini biasanya pada saat kampanye atau kunjungan ke daerah pemilihannya. Pada saat acara telah selesai mereka memberikan barang pemberian pribadi kepada para pemilihnya sebagai kenang-kenangan dan diistilahkan sebagai perekat hubungan sosial untuk menjaga konstituen agar tetap memilih mereka.

Bentuk barang pemberian pribadinya bisa berbagai macam apa saja, seperti kaos, kalender, kipas tangan dan mug yang disertai gambar, nama dan nomor urut yang menunjukan citra diri kandidat. Selain itu, bisa juga berbentuk makanan dan minuman, rokok dan bingkisan lainnya. Individual gift dianggap sebagai tindakan yang lumrah atau wajar dilakukan oleh para caleg disaat melakukan kampanye terbuka, hal itu sudah menjadi tanggung jawab moral caleg terhadap masa pendukungnya untuk memberikan marteri dalam bentuk barang sebagi pelengkap dari serangkaian kampanyenya. Pemahaman yang keliru seperti ini jika dibiarkan begitu saja dalam setiap pemilu akan menjadi budaya yang buruk bagi demokrasi, seharusnya penyelenggara pemilu di tingkatan bawah bisa mengerti hal ini, tahu bahwa apabila caleg yang melakukan itu adalah termasuk kategori dari tindakan politik uang.

\section{Jual Beli Suara (Vote Trading)}

Jual beli suara atau vote tradding dalam pemilu serentak 2019 di Kabupaten Tasikmalaya sangat mungkin terjadi, hal ini biasanya dikarenakan strategi vote buying yang dilakukan caleg dianggap hasilnya akan kurang maksimal maka akan mencari alternatif strategi lain. Aktor yang menjadi sasaran bukan lagi masyarakat yang punya hak pilih tapi sasaran selanjutnya adalah penyelenggara pemilu itu sendiri, mulai dari tingkat yang paling bawah di TPS hingga Komisioner ditingkat Kabupaten baik KPU maupun Bawaslu.

Praktik jual-beli suara antara caleg atau tim sukses dengan penyelenggara pemilu sangat mudah dilakukan, praktik ini lebih senyap dan tidak banyak melibatkan banyak orang, sehingga jarang sekali ada orang yang tau, maka untuk kasus politik uang dengan praktik jual beli suara 
tidak ada satupun temuan laporan yang dilaporkan ke Bawaslu. Akan tetapi bukan berarti tidak terjadi sama sekali praktik jual beli-suara antara caleg atau tim sukses dengan peneyelenggara pemilu. Praktik jual beli suara yang melibatkan penyelenggara pemilu di tingkat Kabupaten mengakibatkan integritasnya runtuh, citra lembaganya buruk dimata masyarakat. Keterlibatan penyelenggara pemilu dalam praktik politik uang mengindikasikan bahwa tidak adanya keseriusan dalam upaya menciptakan budaya demokrasi adiluhung di Kabupaten Tasikmalaya.

Dari beberapa keterangan yang di dapat dari penyelenggara pemilu, tidak ada satupun yang mengakui bahwa dirinya ikut terlibat dalama praktik politik uang, tapi mereka tidak mengelak kalau mereka mengetahui adanya praktik politik uang yang melibatkan penyelenggara yang lain dan mereka enggan menyebutkan siapa namanya apalagi melaporkannya. Praktik politik uang yang banyak melibatkan penyelenggara pemilu mengindikasikan bahwa adanya ketidak beresan dalam proses pelaksanaan perekrutan peneyelenggara pemilu tersebut, tidak netralnya penyelenggara pemilu yang lolos diterima sebagai anggota penyelengga pemilu karena tidak menjalankan sesuai standar prosedurnya. Kinerja KPUD dan Bawaslu Kabupaten Tasikmalaya dalam pelaksanaan rekruitmen panitia peneyelenggara dan panitia pengawas pemilu hasilnya tidak sesuai rencana awal, harapannya bisa mendapatkan penyelenggara pemilu yang berintegritas tapi pada kenyataan yang terjadi banyak penyelenggara yang tidak netral dan menjadi simpatisan partai.

\section{Barang-Barang Kelompok (Club Goods)}

Pemberian barang-barang kelompok (club goods) tidak lepas dari strategi politik uang yang dilakukan oleh para kandidat untuk meraih suara tinggi dalam pemilu serentak 2019 di Kabupaten Tasikmalaya. Sasaran caleg untuk jenis ini bisanya adalah kelompok organisasi atau komunitas yang terbentuk secara formal maupun informal yang berada di daerah pemilihannya caleg tersebut, biasanya meliputi sekup yang lebih kecil setingkat desa bahkan kampung. Kelompok formal biasanya memiliki struktur organisasi atau kepengurusan yang jelas seperti kelompok karang taruna, ikatan remaja mesjid, PKK, lemabaga pendidikan atau pesantren dan lain-lain. Sedangkan untuk kelompok informal lebih ke komunitas hobi atau minat dan bakat seperti kelompok musik, komunitas tari, club sepakbola dan lain-lain.

Kelompok-kelompok diatas menjadi sasaran empuk bagi para caleg untuk melancarkan aksinya, pemberian barang yang di peruntukan kepada suatu kelompok sangat efektif untuk mengurangi anggaran yang harus dikeluarkan oleh kandidat serta hasilnya efisien, seperti pemeberian karpet mesjid untuk sebuah mesjid di suatu kampung dengan jaminan jamaah di kampung tersebut untuk memilihnya. Jelas jika dilihat dari segi anggaran, ini sangat menghemat biaya yang harus dikeluarkan, caleg tidak perlu mengeluarkan uang untuk setiap orang yang berada dikampung tersebut dengan biaya lebih banyak, hal itu sudah tertutup dengan pemberian fasilitas karpet mesjid yang biayanya jauh lebih rendah dan manfaatnya dirasakan bersama, posisi caleg sangat diuntungkan.

Dalam penanganan politik uang jenis ini panitia pengawas dilapangan merasa kewalahan disebabkan bentuknya yang cukup beraneka ragam dan sulit dibedakan mana yang terindikasi politik uang dengan yang bukan politik uang, sehingga tidak ada satupun kejadian yang dilaporkan kepada Bawaslu. Target secara umum yang menjadi sararanya adalah kelompokkelompok yang di dalamnya terlibat banyak anak muda, karena kelompok-kelompok pemuda tersebut aktif mengadakan kegiatan-kegiatan baik di dalam maupun diluar kelompok mereka. Barang-barang yang diberikan juga beragam setiap kelompok berbeda-beda tergantung kelompoknya fokus dibidang apa dan kebutuhannya apa.

\section{Pelayanan dan Aktivitas (services and activities)}

Dalam pemilu serentak tahun 2019 di Kabupaten Tasikmalaya, beberapa caleg dalam upaya memperoleh simpati suara dari pemilih seringkali menyediakan atau memberikan 
dukungan biaya untuk beragam aktivitas dan pelayanan untuk para pemilihnya. Dibeberapa daerah pemilihan di Kabupaten Tasikmalaya praktik seperti itu adalah hal lumrah, terutama dalam kegiatan-kegiatan pengajian yang di adakan oleh majlis taklim, caleg memanfaatkan momen tersebut untuk melakukan pendekatan kepada masyarakat dan mempromosikan diri supaya masyarkat ketika di TPS nanti memilihnya. Tentu saja kegiatan pengajian tersebut disponsori oleh caleg yang diberikan panggung. Ikut dalam acara pengajian dan diberi waktu untuk berbicara dihadapan jamaah pengajian adalah hal yang menguntungkan bagi caleg, apalagi ia bisa berceramah dengan mengutip beberapa ayat sudah pasti respon jamaah kepada caleg tersebut akan baik karena citranya yang religius.

Cara yang berbeda dilakukan oleh caleg lain dari PKS, mereka memfasilitasi pengobatan gratis dan donor darah dalam kemasan acara yang cukup kreatif yang jarang dilakukan oleh partai lain yakni melakukan flashmoob dijalanan terbuka, mereka mencuri start berkampanye sebelum waktunya. Tapi kasus ini hanya mendapat teguran saja dari Bawaslu, alasannya karena ada beberapa hal yang tidak memenuhi persaratan untuk di tindak lebih lanjut.

\section{Poyek-proyek Gentong Babi (Pork Barrel Project)}

Beberapa waktu sebelum pemilu serentak 2019 dilaksanakan, di Kabupaten Tasikmalaya terjadi banyak kasus korupsi penyelewengan berbagai anggaran dana yang dilakukan oleh pemerintah daerah dan wakil rakyatnya. Diantaranya dana aspirasi, dana desa, dan dana hibah, dana rutilahu (rumah tidak layak huni). Hal ini bisa jadi ada hubungannya dengan menjelangnya perhelatan pemilu serentak. Dimana para caleg incumbent memanfaatkan kedudukan mereka sebagai anggota legislatif untuk menaikan elektabilitas dan menjaga konstituennya agar dapat terpilih kembali dalam perhelatan pemilu berikutnya para kandidat petahana tidak hanya mendistribusikan barang patronase (patronage goods), tetapi melakukan politisasi dana aspirasi yang mereka miliki. Upaya ini mereka lakukan dengan mendistribusikan proyek-proyek dana aspirasi ke kelompok masyarakat dalam bentuk proyekproyek pemberian pork barrel (Mahsun, 2015).

Menurut Caporaso dan Levine (2008) penggunanaan layanan publik sebagai alat transaksi, umumnya dilakukan oleh para caleg incumbent, politisi menjual layanan pemerintah kepada masayarakat atau kelompok tertentu dengan imbalan dukungan politik yang diberikan kepadanya, hal ini bekerja secara resiprokal karena pemilih menjual suaranya dengan imbalan berupa layanan publik yang diterimanya.

Incumbent memiliki keunggulan tersendiri karena memiliki akses terhadap sumber daya yang dananya berasal dari permerintah kemudian dananya tersbut bisa disalurkan kepada beberapa kelompok masyarkaat tertentu yang dikehendaki, serta memiliki akses khusus untuk lebih dekat dengan masyarakat karena incumbent sifatnya sebagai pembuat kebijakan (legislasi) yang mengharuskan mereka untuk menampung aspirasi-aspirasi sehingga lebih banyak berinteraksi dengan masyarakat secara langsung. Tentunya hal itu menjadi keuntungan tersendiri bagi incumbent secara tidak langsung menjadi lebih dikenal masyarakat dan juga memiliki kewenangan dalam penyaluran sumber daya.

Distribusi sumber daya dalam politik tidak bisa dilepaskan dari usaha untuk menaikan perolehan suara dan kemenangan dalam perhelatan pemilu, itulah yang menjadi alasan sebagian caleg incubent melakukan strategi politik uang jenis pork barrel projects.

Salah satu karakter politik uang jenis pork barrel projects yang penulis temukan yang terjadi di Kabupaten Tasikmalaya ialah dilakukannya terhadap kelompok tertentu, yakni kelompok keagamaan namun ada juga yang menyasar perangkat pemerintah desa. Jadi menurut panulis, kelompok berbasis agama dan perangkat desa sebagai pemegang kebijakan tertinggi pemerintahan di desa merupakan kelompok yang memiliki peranan penting dalam politik informal, mereka adalah tokoh masyarakat dilingkungannya yang memiliki pengikut dan suaranya didengar sehingga dapat mempengaruhi pilihan masyarkat secara umum. 
Dari uraian jenis-jenis politik uang diatas, penulis berkesimpulan bahwa politik uang bisa dilakukan oleh siapa saja, baik caleg incumbent maupun new comer. Tentu dengan alasan utamanya ingin meraup suara sebanyak-banyaknya untuk meperoleh kursi di parlemen. Hal itu bisa dilakukan oleh kedua golongan caleg tadi apabila memiliki kesempatan dan modal yang cukup banyak terutama dari segi pendanaanya (walaupun modal-modal yang lainnya juga diperlukan), karena hanya caleg yang memiliki banyak uanglah yang memiliki kesempatan lebih besar untuk melakukannya. Sumber dananya bisa darimana saja, ada menggunakan dana tabungan pribadi, ada pula yang disponsori dari kalangan tertentu dan juga dari partai politik, hanya yang terakhir ini tidak bisa diharapkan berapa jumlah nominal yang akan diterimanya.

Terlepas dari sumber pendanaannya darimanapun politik uang yang terjadi di Kabupaten Tasikmalaya menempatkan politik uang jenis vote buying dengan materi uang dan barang menempati urutan pertama yang paling banyak dilakukan oleh caleg karena dianggap strategi yang paling mudah. Pemberian barang dan uang dianggap sebagai hal yang wajar bagi pemilih maupun caleg. Dari sini tampak bahwa manusia adalah makhluk rasional yang selalu mementingkan kepentingan dirinya. Rachbini (2006) mengemukakan bahwa sifat dasariah manusia adalah egois, rasional, dan selalu berupaya untuk memaksimumkan utilitas dan keuntungan bagi dirinya.

\section{Jaringan Praton-Klien Politik Uang}

Dalam memastikan distribusi materi politik uang agar tepat sesuai sararan yang dituju, maka ada pola-pola tertentu yang dilakukan caleg dalam melancarkan aksinya. Diantara yang penulis banyak temukan dilapangan yaitu dengan jaringan yang melibatkan keluarga, tokoh masyarakat, tokoh agama dan perangkat desa. Keterlibatan mereka sangat penting sebagai broker atau agen perantara yang menghubungkan kandidat dan pemilih untuk meraup suara di tingkat akar rumput. Pada umumnya broker akan ada di setiap wilayah atau daerah bahkan di setiap lingkup TPS untuk mencari dukungan masa karena broker diyakini lebih mengetahui kondisi politik, sosial, budaya bahkan geografis di wilayah tersebut. Sehingga dalam melakukan praktik politk uang akan lebih mudah karena telah memahami betul situasi dan kondisi dilapangan.

Broker diyakini mampu menyampaikan, mengontrol dan bahkan menuntut kepatuhan pemilih oleh sebab itu broker sangat paham dengan kondisi sebenarnya di lapangan jika ada penerima uang, barang atau materi lainnya mendukung atau tidak mendukung caleg yang di tujukan. Keterlibatan broker menjadi acuan dalam setiap penyelenggaraan pemilu sebagai pola yang paling efektif untuk dijalankan. Berikut adalah beberapa bentuk jaringan broker suara dalam mendistribusikan materi politik uang dalam pemilu serentak 2019 di Kabupaten Tasikmalaya:

\section{Tim Sukses}

Dalam setiap perhelatan pemilu legislatif, kandidat pastinya akan membentuk tim pemenangan atau tim sukses untuk memperoleh suara yang banyak demi kemenangannya. Tim sukses bersifat personal dan bertugas untuk mempromosikan dan mengkampanyekan kandidat secara idividual ataupun terkadang tim suskses bisa terlibat kampanye tandem dengan beberapa kandidat yang berbeda tingkatan pencalonannya. Biasanya orang yang dipilih untuk menjadi tim sukses adalah orang dekat atau orang kepercayaan kandidat, bisa dari lingkungan keluarga, relasi pekerjaan, teman dekat ataupun dari pengurus partai.

Tim sukses bisa dikelompokan menjadi dua macam, yaitu tim sukses resmi (formal) dan tim sukses bayangan (informal). Tim sukses resmi ialah tim yang dibentuk secara khusus dengan struktur yang jelas serta terdaftar keanggotaanya di KPU, cara kerjanya pun lebih terstruktur dan bersih, terbebas dari praktik-partaktik kecurangan yang melanggar aturan pelaksaanaan pemilu, bilamana ada keterlibatan melakukan pelanggaran pun akan ditindak 
lanjuti dengan lebih mudah karena KPU sudah memiliki data daftar nama anggota tim suksesnya. Hal itu juga akan mempermudah Bawaslu untuk melakukan penindakannya. Beda halnya dengan tim sukses bayangan, tim ini sengaja di bentuk untuk memaksimalkan strategi kemenganan kandidat, hanya saja tidak terdaftar resmi di KPU. Karena biasanya tim ini lah yang sering melakukan kecurangan dan pelanggaran-pelanggaran pemilu termasuk prakatik politik uang. Sehingga apabila ada laporang pelanggaran yang dilakukan tim bayangan ini akan sulit untuk diproses karen ketidak jelasan administrasinya yang tidak terdaftar di KPU. Di dalam tim inilah para broker bernaung waluapun tidak semua tim sukses bayangan berarti broker. Pada dasarnya tim sukses banyangan sengaja di bentuk bertujuan untuk mengelabui aturan yang berlaku Baik caleg maupun tim sukses bayangan sama-sama mengakui bahwasannya cara kerja dari tim suskses yang tidak terdaftar resmi di KPUD memang bertujuan untuk melakukan pemenangan kandidat dengan cara-cara yang tidak diindahkan sebagaimana yang diatur dalam undang-undang pemilu maupun aturan pemilu lainnya. Tidak ada kehawatiran apa lagi ketakutan diantara mereka terhadap acaman pelanggaran hukum dalam pemilu jika terbukti melakukannya karena mereka paham celah hukumnya dimana dan mereka meyakini bisa mengelabui aturan tersebut.

Pada umumnya para kandidat membentuk tim sukses dengan struktur segitiga atau piramida yang semakin kebawah semakin banyak anggotanya, mereka memiliki tim sukses yang berada dilingakaran utama yang diisi oleh tim inti yang di dalamnya ada ketua, penasehat dan beberapa anggotanya, kebawahnya ada koordinator kecamatan (korcam), tiap korcam membentuk koordinator desa (kordes) dan terakhir adalah koordinator lapangan (korlap) yang bersinggungan langsung dengan pemilih dan beberapa yang menempati ini adalah broker. Broker bertujuan untuk menghubungkan kandidat yang posisinya berada pada puncak piramida dengan para pemilih yang berada pada level paling bawah piramida. Dalam menjalankan tugasanya, broker pada tingkatan kampung atau RT/RW akan mencari orang terdekat dilingkungannya dan memasukannya ke daftar nama pemilih yang akan bersedia memberikan suaranya kepada kandidat nanti ketika hari $\mathrm{H}$ pemilihan, kemudian memberikan daftar nama tersebut kepada tim sukses diatasnya, memberikan uang dan memastikan para penerima uang datang ke TPS pada hari pemilihan. Tim sukses yang melibatkan jaringan keluarga dalam melakukan kerjanya bisa lebih dinamis, tanpa ada intruksi atau perintah khusus dan berlebihan, karena biasanya tim suskses dari anggota keluarga paham kapan mereka harus bekerja. Tim sukses yang melibatkan jaringan keluarga cara kerjanya hampir sama dengan cara tim sukses pada umumnya. Hanya saja tim sukses yang bekerja di dalam jejaring kekeluargaan ranahnya lebih kecil yaitu masih dilingkaran keluarnganya.

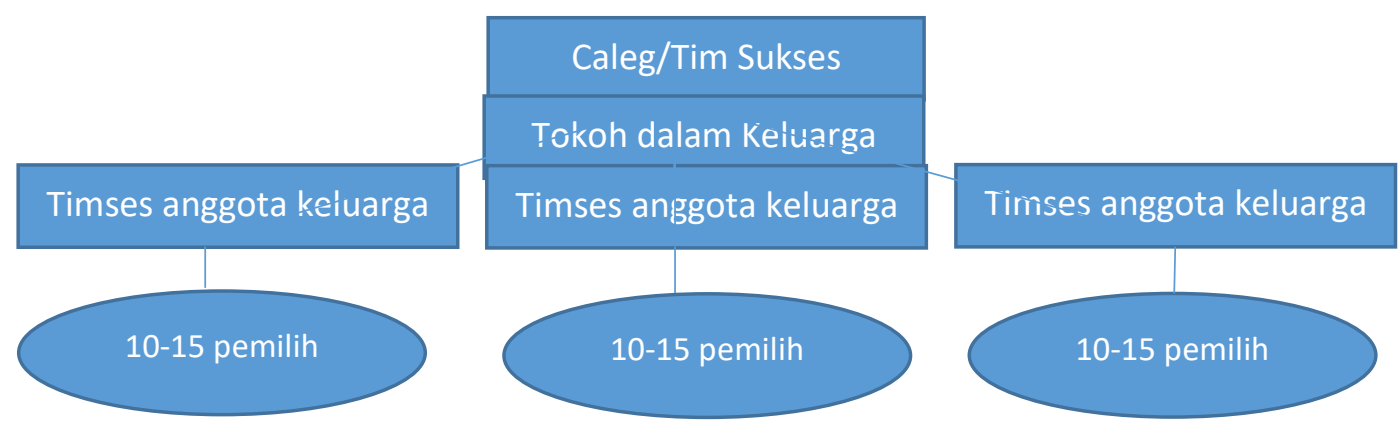

Gambar 1. Struktur tim sukses dalam jaringan keluarga

Dalam melakukan pekerjaaanya setiap anggota keluarga ditugaskan untuk mendata dan membagikan uang kepada beberapa orang sebanyank 10-15 pemilih. Mereka diamanahkan dan bertanggung jawab penuh untuk mengawal dan memastikan hingga hari pencoblosan tiba. Pola struktur diatas juga menunjukan bahwa dalam keluarga ada yang menjadi sosok panutan atau 
ditokohkan yang nantinya mampu menjadi penghubung antara caleg dengan anggota keluarga lainnya.

\section{Jaringan Sosial}

Pelibatan tokoh masyarakat dalam setiap perhelatan pesta demokrasi tidak luput dari bidikan para caleg untuk memperoleh dukungannya, karena dari pengaruh jaringan sosial yang mereka miliki bisa diarahkan untuk memberikan dukungan kepada para kandidat. Keberadaan tokoh masyarakat ini seringkali memiliki jabatan formal dalam sebuah institusi pemerintah ataupun jabatan informal misalnya sebagai tokoh agama, pimpinan ormas atau orang biasa yang dianggap peting oleh lingkungannya. Harapannya dengan memanfaatkan para tokoh masyarakat ini, mereka dapat mendorong para pengikutnya untuk mendukung caleg tersebut. Seringkali jaringan sosial yang telah ada dimanfaatkan kepercayaan sosialanya untuk mendapatkan dukungan politik.

Pelibatan tokoh masyarakata dalam strategi pemenangan caleg dalam pemilu terbukti menjadi salah satu kunci untuk memperoleh suara yang banyak dari para pemilih. Tidak luput tokoh agama juga menjadi sasaran target caleg untuk di dekati dan dimanfaatkan pengaruh ketokohanya yang memiliki banyak pengikut, pasalnya tokoh agama memiliki pesantren dan pesantren memiliki legitimasi sosial di masyarakat sehingga mampu mengarahkan mayarakat yang memiliki suara untuk memilih caleg yang di restui oleh pimpinan pesantren. Beberapa tokoh pesantren di Tasikmalaya pada dasarnya memiliki kepiawaian untuk berafiliasi dengan beberapa partai politik dan ini sudah sejak lama terjadi, biasanya dengan partai islam yang basis anggotanya kebanyakan dari kalangan NU, di Tasikamlaya sendiri banyak tersebar persanten NU. Oleh sebab itulah keberadaan jaringan tokoh agama dari lingkungan pesantren menjadi modal politik dalam kontestasi politik elektoral.

Pelibatan tokoh masyarakat lainnya terjadi di dapil 7, tepatnya di Kecamatan Salawu, Sondong Hilir, Bojong Gambir, Taraju dan Puspahiang. Hampir semua parpol besar di dapil 7 ini membangun jaringan dengan oraganisasi masyarakat yang cukup berpengaruh di wilayahnya masing-masing. Partai politik membina organisasi tersebut dengan tujuan untuk memelihara konstituennya supaya tetap loyal. Melibatkan oramas sebagai stategi pemenangan caleg adalah stategi yang tepat, jaringan sosial menjadi salah satu kunci utama untuk menyasar pemilih ditataran paling bawah. Hubungan partai politik dengan ormas setempat adalah patronase politik yang saling menguntungkan. Mereka menukarkan keuntungan satu samalain, caleg biasanya memberikan materi seperti uang atau barang bahkan jasa, mendukung atau mensponsori kegiata-kegiatan yang diselenggarakan oleh ormas tersebut, beberapa tokoh anggota ormas juaga ada yang mendapat tawaran pekerjaan. Sedangkan timbal balik yang diberikan ormas kepada caleg dengan cara memberikan suara anggotanya untuk memilih mereka dan memobilisisi pemilih yang lain supaya mendukung dan memilih caleg yang telah memberikan keuntungan kepada oramas mereka.

\section{Partai Politik}

Peran partai politik dalam mendukung kandidat pada sistem pemilu proposional terbuka tidak begitu banyak diandalkan. Sistem pemilu proposional terbuka menjadikan persaingan caleg diinternal partai menjadi lebih sengit dibandingkan dengan persaingan caleg antar partai yang berbeda, sehingga pengurus partai tentunya akan lebih selektif dalam membagi tugas anggotanya untuk berperan mendukung kandidat yang mana. Hanya saja apabila kandidat yang dicalonkan adalah kader partai yang menjabat sebagai pengurus utama partai (misalnya ketua partai) tersebut bisa saja mendominasi partai dan membuat kepengurusan partai tersebut dijadikan kepentingan pribadinya sebagai tim sukses.

Keterlibatan kader partai politik sebagai tim pemenangan terhadap caleg yang bukan dari pengurus inti partai tidak dilibatkan sama sekali, pembagian tugas terhadap para anggota partai 
politik di atur oleh pimpinan partainya sendiri, tentu disana yang akan diutamakan untuk mendapat dukungan penuh dari partai politik adalah caleg yang sekaligus kader partai politik yang menduduki jabatan inti di dalam partainya. Sulit bagi mereka (caleg yang bukan pengurus inti partai) untuk mendapat dukungan dari internal kader partai politik, pada akhirnya mereka hanya bisa mengandalkan jaringan sosianya sendiri untuk dilibatkan menjadi tim suksesnya.

Kader partai politik yang dilibatkan untuk mendukung caleg biasanya mereka menduduki tim sukses yang statusnya formal atau terdaftar di KPUD, sehingga mereka tidak akan sembarangan melakukan hal-hal yang akan berdampak merugikan caleg, partai politik dan juga diri mereka sendiri semacam melanggar aturan-aturan pemilu ataupun melakukan praktik politik uang, karena apabila hal semacam itu terjadi dan dilaporkan semuanya akan menjadi sia-sia, caleg yang mereka dukung walaupun menang akan didiskualifikasi dan mendapat hukuman pidana, begitupun sama bagi tim sukses yang melakukan pelanggarannya akan di adili. Contohnya seperti salah satu caleg Partai Gerindra dari dapil 7 Kabupaten Tasikmalaya, baik caleg maupun tim suksesnya sama-sama mendapatkan hukuman. Jadi pola politik uang yang melibatkan kader partai politik kemungkinan akan jarang ditemukan. Tapi hal itu tidak menutup kemungkinan hal yang sebaliknya, praktik politik uang akan terjadi juga jika kondisinya memang memungkinkan dan ada kesempatan.

Dari uraian diatas, dapat dipahami bahwa struktur broker yang terbentuk dalam pemilu serentak 2019 di Kabupaten Tasikmalaya menggunakan dua model yang berbeda untuk menjangkau pemilih di akar rumput, yaitu jalur pertama melalui patai politik ataupun tim sukses dalam hal ini yang didominasi oleh hubungan kekeluargaan dan kedua melalui jaringan sosial.

Praktik politik uang yang marak terjadi pada perhelatan pemilu serentak tahun 2019 di Kabupaten Tasikmalaya tentunya berdampak pada meningkatnya partisipasi pemilih, pada pemilu 2014 partisipasi pemilih di Kabupaten Tasikmalaya mencapai angka 65 persen dan terjadi kenaikan partisipasi pemilih pada pemilu serentak tahun 2019 menjadi 71 persen. Kenaikan partisipasi pemilih selain karena kinerja sosialisasi KPU salah satunya ditunjang oleh praktik politik uang yang marak terjadi.

\section{KESIMPULAN DAN SARAN}

Jenis politik uang pada pemilu serentak di Kabupaten Tasikmalaya pada tahun 2019 sangat berfariasi, hampir semua jenis politik uang di temukan, diantaranya sebagai berikut: Vote buying, bentuk vote buying terbagi menjadi uang dan barang, keduanya ditemukan dalam kasus politik uang di Kabupaten Tasikmalaya. Ada lima laporan vote buying yang diterima resmi oleh Bawaslu, 1 diantaranya bisa di tangani sampai putusan pengadilan, sedangkan 4 lainnya tidak diproses lebih lanjut karena tidak memenuhi unsur formil dan materil. Sedangkan vote buying dalam bentuk barang tidak ada laporan resmi ke Bawasalu, namun dalam pemantauannya Bawaslu dan Panwasa Desa mengakui adanya caleg yang membagi-bagikan barang. Seperti perlengkapan ibadah. Individual gifts, beberapa temuan yang menyangkut individual gifts di Kabupaten Tasikmalaya dianggap sebagai hal yang lumrah, ada pemahaman keliru bahwasannya praktik individual gifts tidak masuk kedalam kategori politik uang, karena sifatnya yang memberi barang tersebut hanya sekedar tanggung jawab moral. Individual gift pada akhirnya tidak begitu di sorat dan hanya dibiarkan begitu saja.

Vote Tradding, kasus keterlibatan penyelenggara pemilu di Kabupaten Tasikmalaya menyoroti beberapa penyelengara berbagai tingkatan, diantanya salah satu Komisioner Bawaslu Kabupaten Tasikmalaya terlibat dalam pengawalan suara atau C1 palano dengan mendapat imbalan dari caleg untuk setiap kecamata diberi 500 rb. Sedang beberapa kasus yang menyinggung penyelenggara lainnya seperti PPK dan Panwascam kebawahnya hanya persoalan netralitas dan integritas pekerjaannya, karena masih banyak yang menunjukan keterpihakan terhadap partai atau caleg, sedangkan laporan ada atau tidaknya penyelenggara 
yang menerima uang tidak jelas keberadaaanya. Club goods, pemberian barang-barang kelompok kepada masyarakat yang tergabung dalam suatu kelompok atau komunitas menyasar kepada dua kelompok, yaitu kelompok kepemudaan dan kelompok keagamaan. Services and activities, sasaran caleg dalam praktik aktivitas ini menyasar kepada kegiatan-kegiatan keagamaan, misalnya pengajian, dalam acara tersebut caleg mensponsori penuh kegiatannya dan timbal baliknya ia diberi panggung dalam acara tersebut. Sedangkan pelayanan adanya fasilitas pelayanan pengobatan gratis dan donor darah yang diselenggarakan oleh PKS dengan kemasan acara flashmob yang unik.

Pork Barrel Project, ada dua temuan dalam kasus ini yang menyangkut dengan pemilu serentak di Kabupaten Tasikmalaya tahun 2019, yakni kasus dana hibah bantuan sosial yang melibatkan pimpinan DPRD Kabupaten Tasikmalaya dan kasus dana bantuan desa yang melibatkan Kepala Desa Sukaheuning dan Anggota Dewan. Dari keenam jenis politik uang tersebut, kasus yang paling dominan ditemukan adalah vote buying, ditunjukan dengan adanya sebanyak lima laporan yang masuk ke Bawaslu, sedangkan jenis politik uang yang lainnya tidak ada sama sekali. Hal itu dikarenakan vote buying paling mudah ditemukan, karena uang dan barang yang beradar saat pemilu sangat banyak dan lebih terbuka. Minimnya pemahaman masyarakat terhadap jenis-jenis politik uang, sehingga yang mereka tau hanya vote buying dalam bentuk barang dan uang. Strategi politik uang juga berpengaruh signifikan terhadap meningkatnya partisipasi pemilih di Kabupaten Tasikmalaya.

Pola politik uang pada pemilu serentak di Kabupaten Tasikmalaya pada tahun 2019 terbagi menjadi 3 pola, yaitu: Jaringan Tim Sukses. Terdapat dua kategori tim sukses, pertama tim sukses resmi, kedua tim sukses bayangan. Dalam pemilu serentak ini caleg lebih banyak melibatkan tim sukses bayang atau tidak remi yang ia tentukan sendiri dan kebanyakan melibatkan tim sukses jaringan keluarga. Jaringan Sosial. Beberapa partai besar membentuk afiliasi atau sayap partai dengan ormas-ormas setempat dan secara personal caleg memanfaat tokoh masyarakat dalam bidang agama (kyai) yang memiliki jamaah yang banyak untuk mendukungnya. Partai politik. Pola ini tidak banyak diandalkan oleh para caleg, karena sistem pemilu serentak yang digunakan adalah sistem proposional terbuka yang pada akhirnya menuntut persaingan atar caleg dalam satu partai. Sehingga kader partai dilibatkan hanya kepada caleg yang memiliki posisi penting di partainya. Broker suara dalam menjangkau pemilih diakar rumput melalui tiga pola diatas, yaitu jaringan tim sukses yang didominasi oleh hubungan kekeluargaan dan jaringan sosial, sedangkan partai politik hanya diandalkan oleh caleg yang menjabat sebagi pimpinan dipartainya.

Adapun beberapa saran dari penelitian ini sebagai berikut: Melakukan seleksi yang ketat kepada seluruh penyelenggara pemilu di semua tingkatan, supaya tidak adalagi anggota penyelenggara yang tidak berintergritas dan memihak salah satu partai. Kemudian perlu adanya peningkatan kapasitas sumber daya penyelenggara pemilu dalam menjalankan tugas dan fungsinya masing-masing. Membentuk lembaga atau kelompok khusus baik resmi di bawah pemrintah ataupun bersifat independen pada tingkat pemrintahan paling bawah yaitu Desa dan pemerintah Desa bisa membuat perdes atau gerakan Desa anti politik uang.

\section{DAFTAR PUSTAKA}

Agustino, L. (2014). Patronase Politik Era Reformasi: Analisis Pilkada di Kabupaten Takalar dan Provinsi Jambi. Administrasi Publik, 11 (2), 3.

Al-Rasyid, H. (2017). Fikih Korupsi. Jakarta: Kencana.

Amarru Muftie Holish, R. d. (2018). Money Politic dalam Praktik Demokrasi Indonesia. Jurnal Unnes, 228-237.

Ashiddiqie, J. (2012). Pengantar Ilmu Hukum Tata Negara. Jakarta: Rajawali Pers. 
Asnawi. (2016). Penegakan Hukum Tindak Pindana Politik Uang Pemilihan Umum Legislatif pada Masa Kampanye di Kabupaten Serang. Jurnal Mimbar Justitia, 765-784.

Aspinall, E., \& Sukmajati, M. (2015). Patronase dan Klientelisme dalam Politik Elektoral di Indonesia. Dalam E. Aspinall, \& M. Sukmajati, Politik Uang di Indonesia:

Pantronase dan Klientelisme pada Pemilu Legislatif 2014 (hal. 1-49). Yogyakarta: PolGov.

Aspinall, E., \& Sukmajati, M. (2015). Politik Uang di Indonesia: Patronase dan Klientelisme pada Pemilu Legislatif 2014. Yogyakarta: PolGov.

Aswad. (2015). Kabupaten Kapuas: Peran Uang, Barang dan Keluarga dalam Memenangkan Caleg. Dalam E. Aspinall, \& M. Sukamajati, Politik Uang di Indonesia: Patronase dan Klienteliseme pada Pemilu Legislatif 2014 (hal. 430-456). Yogyakarta: PolGov.

Bawaslu. (2018). IKP 2019 Indeks Kerawanan Pemilu Legislatif dan Presiden. Jakarta: Bawaslu Republik Indonesia.

Budiarjo, M. (2008). Dasar-Dasar Ilmu Politik. Jakarta: PT Gramedia Pustaka Utama.

Capraso, J. A., \& Levine, D. P. (2008). Teori Ekonomi Politik. Yogyakarta: Pustaka Pelajar.

Darmawan, C. (2009). Memahami Demokrasi Perspektif Teoritis dan Empiris. Bandung: Pustaka Aulia Press.

Djaelani, A. R. (2013). Teknik Pengumpulan Data dalam Penelitian Kualitatif. Pawiyatan, 20.

Habibullah, A. (2017). Politik Uang Pilkada Serentak Tahun 2015 di Kabupaten Ogan Ilir. Yogyakarta.

Halili. (2009). PRAKTIK POLITIK UANG DALAM PEMILIHAN KEPALA DESA. Jurnal Humaniora (Lemlit UNY), 99-112.

Hamdi, A. Z. (2015). Madiun, Jawatimur: Peran Broker dalam Strategi Teritorial, Jaringan Sosial dan Pembelian Suara. Dalam E. Aspinall, \& M. sukmajati, Politik Uang di Indonesia: Patronase dan Klienteliseme pada Pemilu Legislatif 2014 (hal. 403-429). Yogyakarta: PolGov.

Hanif, H. (2009). Politik Klientelisme Baru dan Dilema Demokrasi di Indonesia. Jurnal Ilmu Sosial dan Ilmu Politik, 12 (3), 325-390.

Haryanto. (1984). Partai Politik Sebagai Tinjauan Umum. Yogyakarta: Liberty.

Hefni, M. (2012). Patron-Client Relationship pada Masyarakat Madura. KARSA: Jurnal Sosial dan Budaya Keislaman, 15(1), 15-24.

Ichsan, F. (2016). Hubungan Patron Klien dalam Pemilihan Kepala Desa di Desa Kampala. Yogyakarta.

Izza, I. L. (2016). Pengaruh Money Politics Terhadap Pemilih Pemula dalam Pemilihan Kepala Desa Sidomukti Kecamatan Margoyoso Kabupaten Pati tahun 2015. Yogyakarta.

Lasmana, T. (2009). Praktik Politik Uang dalam Pemilihan Kepala Desa ( Studi di Desa Pakandangan Barat Bluto Sumenep Madura. Humaniora.

Mahsun, M. (2015). Kota Palembang, Sumatera Selatan: Dana Aspirasi dan Politik Klientelisme. Dalam E. Aspinall, \& M. Sukmajati, Politik Uang di Indonesia: 
Patronase dan Klientelisme pada Pemili Legislatif 2014 (hal. 174-199). Yogyakarta: PolGov.

Mohammad Najib, B. S. (2014). Pengawasan Pemilu, Problem dan Tantangan. Yogyakarta: Bawaslu Provinsi DIY.

Moleong, L. J. (2007). Metodelogi Penelitian Kualitatif (14 ed.). Bandung: PT Remaja Rosda Karya.

Muhtadi, B. (2013). Politik Uang dan Dinamika Elektoral di Indonesia: Sebuah Kajian Awal Antara "Party-ID" dan Patron-Klien. Jurnal Penelitian Politik, 42-44.

Muhtadi, B. (2018). Komoditas Demokrasi: Efek Sistem Pemilu terhadap Maraknya Jual Beli Suara. Dalam M. Sukmajati, \& A. Perdana, Pembiayaan Pemilu di Indonesia (hal. 9117). Jakarta: Bawaslu (Badan Pengawas Pemilihan Umum) Republik Indonesia.

Pratama, R. A. (2017). Patronase dan Klientelisme pada Pilkada Serentak Kota Kendari. Jurnal Wacana Politik, vol 2, 33-45.

Rahcbini, D. J. (2006). Ekonomi Politik dan Teori Pilihan Publik. Bogor: Ghalia Indonesia.

Rahmatilah. (2015). Sikap dan Pengetahuan Masyarakat Terhadap Money Politikl dalam Pemilu Legislatif Tahun 2014. Al-daulah, 375-390.

Ramli, M. (2016). Patronase Politik dalam Demokrasi Lokal. Makasar.

Santosa, P. B. (2006). Gangguan Politik Uang dalam Pembangunan. Dinamika Ekonomi \& Bisnis, 3.

Scott, J. C. (1972). Patron-Client Politics and Political Change in Southeast Asia. Apsa, 91113.

Supriansyah, M. (2017). Money Politic Dalam Pemilu Menurut Pandangan Hukum Islam dan Undang-Undang. Lampung.

Suprianto, D. (2017). Analisis Politik Uang pada Pilkada GubernurnProvinsi Bengkulu tahun 2015. Tesis, MIP UMY. Yogyakarta.

Wahab, S. A. (1999). Analisis Kebijakan Publik Teori dan Aplikasinya. Malang: Danar Wijaya.

Wahid, M. (2015). Cirenbon, Jawa Barat: Ketika Patronase mengalahkan Personalisme. Dalam E. Aspinall, \& M. Sukmajati, Politik Uang di Indonesia: Patronase dan Klientelisme pada Pemilu Legislatif 2014 (hal. 294-352). Yogyakarta: PolGov.

Widioyono, S. S. (2013). Metodelogi Penelitian Sosial untuk Penulisan Skripsi dan Tesis. Jakarta: In Media.

Yustika, A. E. (2010). Ekonomi Kelembagaan, Definisi, Teori dan Strategi. Malang: Bayu Media Publishing.

Zaman, r. k. (2016). perjalanan panajang pilkada serentak. bandung: mizan. 